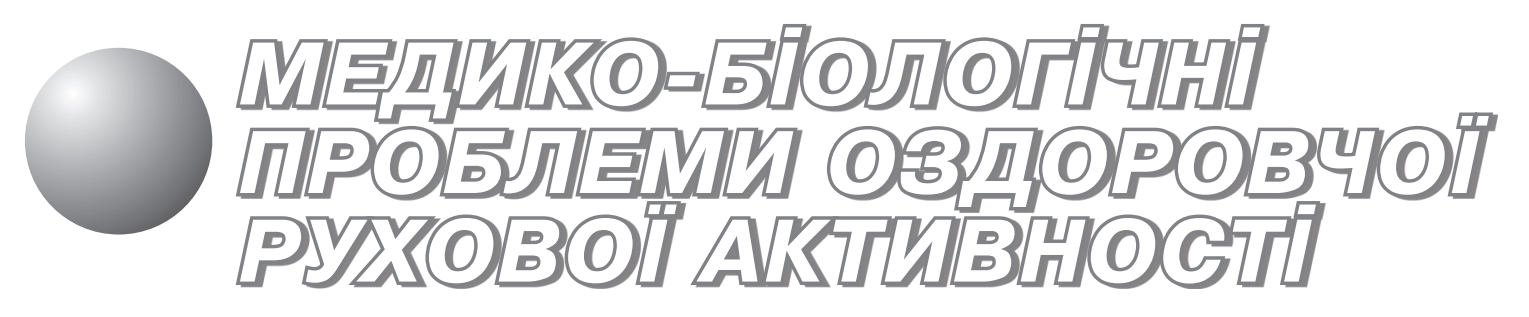

DOI: https://doi.org/10.32652/spmed.2018.2.40-44

\title{
Методичні основи побудови технології фізичної реабілітації для жінок першого зрілого віку з порушенням енергетичного обміну та ожирінням
}

\author{
УдК 796:617.586-053.4-085+061.237-055.15
}

\section{М. В. Береговий, і. О. Жарова, Л. Д. Кравчук}

Національний університет фізичного виховання і спорту України, Київ, Україна

\begin{abstract}
Резюме. Мета. Охарактеризувати методичні основи побудови технології фізичної реабілітації жінок першого зрілого віку з порушенням енергетичного обміну та ожирінням та оцінити ефективність запропонованої технології. Методи. Теоретичний комплексний аналіз науковометодичної літератури та джерел, інструментальні методи досліджень (дистанційний метод вимірювання складу тіла BC-418MA TANITA). Результати. Проаналізовано результати власних досліджень лікування 48 жінок із порушенням енергетичного обміну та ожирінням I ступеня. На підставі отриманих результатів встановлено, що розроблена технологія диференційованого підбору навантажень для жінок з ожирінням показала досить високу ефективність. Додаткові танцювальні заняття та вправи аеробної спрямованості дозволяють знизити об'єм адипоцитів підшкірної жирової тканини, що сприяє зниженню загальної маси тіла та зменшенню частки жирової тканини. Висновки. На підставі проведених клініко-інструментальних методів досліджень у жінок першого зрілого віку з порушенням енергетичного обміну та ожирінням І ступеня, які займалися аеробними фізичними тренуваннями, на заняттях танцетерапії отримано більш ефективні результати, що підтверджує її пріоритет під час вибору тактики лікування екзогенно-конституціонального ожиріння у жінок першого зрілого віку.
\end{abstract}

Ключові слова: технології фізичної реабілітації, порушення енергетичного обміну, ожиріння.

\section{Методические основы построения технологии физической реабилитации для женщин первого зрелого возраста с нарушением энергетического обмена и ожирением}

М. В. Береговой, И. А. Жарова, Л. Д. Кравчук

Национальный университет физического воспитания и спорта Украины, Киев, Украина

Резюме. Цель. Охарактеризовать методические основы построения технологии физической реабилитации для женщин первого зрелого возраста с нарушением энергетического обмена и ожирением и оценить эффективность предложенной технологии. Методы. Теоретический комплексный анализ научно-методической литературы и источников, инструментальные методы исследований (дистанционный метод измерения состава тела BC-418MA TANITA). Результаты. Проанализированы результаты собственных исследований лечения 48 женщин с нарушением энергетического обмена и ожирением I степени. На основании полученных результатов установлено, что разработанная технология дифференциального подбора нагрузок для женщин с ожирением показала достаточно высокую эффективность. Дополнительные танцевальные занятия и упражнения аэробной направленности позволяют снизить объем адипоцитов подкожной жировой ткани, что способствует снижению общей массы тела и уменьшению удельного веса жировой ткани. Выводы. На основании 
проведенных клинико-инструментальных методов исследований у женщин первого зрелого возраста с нарушением энергетического обмена и ожирением I степени, которые занимались аэробными физическими тренировками, на занятиях танцетерапии получены более эффективные результаты, подтверждающие ее приоритет при выборе тактики лечения экзогенно-конституционального ожирения женщин первого зрелого возраста.

Ключевые слова: технологии физической реабилитации, нарушение энергетического обмена, ожирение.

\title{
Methodical bases of designing physical rehabilitation technology for women of the first mature age with energy metabolism disorders and obesity M. V. Berehovyi, i. O. Zharova, L. D. Kravchuk
}

National University of Physical Education and Sport of Ukraine, Kyiv, Ukraine

\begin{abstract}
Aim. To characterize methodical bases of designing physical rehabilitation technology for women of the first mature age with energy metabolism disorders and obesity, and to evaluate the effectiveness of proposed technology. Methods. Theoretical complex analysis of scientific and methodical literature and sources, instrumental methods of research (distance measurement method of body composition BC-418MA TANITA). Results. The results of own research of treatment of 48 women with energy metabolism disorders and obesity of the 1st degree have been analyzed. On the basis of findings it was established that the developed technology of differentiated selection of loads for women with obesity has shown rather high efficiency. Additional dance lessons and exercises of aerobic orientation allow to reduce the volume of adipocytes of subcutaneous adipose tissue, which helps to reduce the total body weight and the proportion of adipose tissue. Conclusions. Based on conducted clinical and instrumental research methods in women of the first mature age with energy metabolism disorders and obesity of the I degree engaged in aerobic physical training, more effective results were observed during dance lessons, which confirms its priority in choosing the tactics of treatment of exogenous and constitutional obesity in women of the first mature age.

Keywords: physical rehabilitation technologies, energy metabolism disorders, obesity.
\end{abstract}

Постановка проблеми. Відповідно до сучасних уявлень, ожиріння - поліетіологічне захворювання, пов'язане з багатьма фракторами (значним збільшенням споживання висококалорійної їжі, помітним зниженням фрізичної активності, зменшенням загальних енерговитрат організму, генетичною схильністю, порушенням функції ендокринної системи). За даними Всесвітньої організації охорони здоров'я (ВООЗ), близько 1,7 млрд людей мають надлишкову масу тіла або ожиріння (International Obesity Task Forse, Collated data, 2003) [9].

В Україні, наприклад, від 23 до $25 \%$ чоловіків і від 28 до $30 \%$ жінок мають ожиріння $[1,5]$. У країнах Західної Європи частка людей, які мають таку патологію, досягає $27 \%$, а у США та Канаді - 35-37\%. Збільшення кількості хворих, що страждають на різні форми ожиріння, особливо серед осіб молодого працездатного віку, викликає тривогу в усьому світі, привертає увагу до вивчення різних аспектів цієї проблеми терапевтів, ендокринологів, патофрізіологів, гігієністів і представників інших медичних спеціальностей $[7,8]$.

Аналіз останніх досліджень і публікацій. Соціальна значущість цієї патології обумовлена активним віком хворих (25-50 років), а також швидко прогресуючим характером захворювання, що проявляється численними клінічними сим- птомами і вираженими метаболічними порушеннями, часто спричиняє тяжкі фрункціональні та структурні зміни різних органів і систем організму. У хворих на ожиріння значно частіше констатують розвиток таких серйозних захворювань, як атеросклероз, цукровий діабет, подагра, що призводить до ранньої інвалідизації та зменшення середньої тривалості життя людини $[1,2,4]$.

Однак не всі питання, пов'язані з причинами виникнення порушень енергетичного обміну, вивчено до кінця. В основі розвитку ожиріння лежить енергетичний дисбаланс, який полягає у невідповідності між кількістю калорій, що надходять із їжею, та енергетичними витратами організму [2, 7]. Патогенез розвитку ожиріння надзвичайно складний і $є$ результатом порушення механізмів підтримання нормальної кількості жиру в організмі. У ньому беруть участь багато фракторів, тісно пов'язаних між собою $[4,7]$.

До факторів, що сприяють розвитку ожиріння, належать: особливості генотипу, особливості конституції жирової тканини, особливості гормональної регуляції процесів ліполізу та ліпогенезу, порушення функції центрів насичення, психічні i емоційні розлади, сімейні та національні звички в харчуванні, умови цивілізації, що зазвичай діють у поєднанні один з одним [2, 4, 9]. 
Дисбаланс енергії $€$ наслідком неадекватної взаємодії генетичних фракторів (виявлено гени, що відповідають за накопичення і розподіл жиру в організмі) і зовнішнього середовища (соціальних, харчових, психологічних, фрізичних навантажень). Вплив зовнішніх фракторів на анаболічні процеси в організмі реалізується через центральну нервову й ендокринну системи. При цьому центром енергетичного балансу, куди надходять нейрогуморальні сигнали з різних відділів мозку та інших органів, $\epsilon$ гіпоталамус. Саме порушенням функції гіпоталамічних структур, які регулюють надходження та витрачання енергії, відводять основне значення в генезі ожиріння $[1,5]$.

Гіпоталамічні структури управляють витратою енергії через вегетативну нервову систему, з допомогою гормонів гіпофіза, широко залучаючи до цього процесу всю ендокринну систему [1]. Доведено, що активація гіпоталамо-гіпофрізарнонадниркової системи поєднується 3 ожирінням як у тварин, так і у людини [1, 4]. На харчові пристрасті, частоту прийомів їжі впливають нейромедіатори. Одні з них (нейропептид Y, галанін, опіоїди, соматоліберин) сприяють збільшенню, а інші (серотонін, норадреналін, дофамін, кортиколіберин, холецистокінін) - зниженню споживання їжі [5, 7].

Порушення у фонкціонуванні складної багатокомпонентної системи регулювання споживання енергії їжі та ії̈ витрачання часто призводять до підвищеної харчової мотивації і надмірного споживання їжі [3, 5]. Формування ожиріння пов'язано з такими станами організму при цьому захворюванні, як гіперінсулінемія та інсулінорезистентність, а також зі зниженою специфічною динамічною дією їжі, оскільки всі перераховані зміни безпосередньо впливають на розвиток станів голоду і насичення [2].

Останніми роками розроблено і впроваджено в клінічну практику достатню кількість методів дослідження розмірів і кількості жирових клітин, метаболізму жирової тканини, особливостей обміну речовин під час ожиріння, стану органів i систем при різних його формах $[3,6,10]$.

Ці дослідження дозволяють рекомендувати нові, більш досконалі методи лікування. У разі безуспішності консервативної терапії розробляються показання і методики оперативного лікування, більш ефективні комплекси лікувальної гімнастики та методики проведення масажу. Захворювання обміну речовин лікують комплексно, за допомогою медикаментів, гормонів, дієтотерапії, засобів фрізичної реабілітації $[3,9,10]$. Але підхід до пацієнтів повинен бути індивідуальним, а складена програма має бути універсальною, 3 урахуванням і визначенням загальних особливос- тей для всіх пацієнтів з екзогенним ожирінням на ранніх стадіях. Все це обумовило актуальність проблеми і дозволило сформулювати мету нашого дослідження.

Мета дослідження - охарактеризувати методичні основи побудови технології фрізичної реабілітації жінок першого зрілого віку з порушенням енергетичного обміну та ожирінням та оцінити ефективність запронованої технології.

Матеріали та методи дослідження. Теоретичний аналіз науково-методичної літератури, інструментальні методи обстеження (дистанційний метод вимірювання складу тіла ВС-418МА TANITA).

У дослідженнях взяли участь 48 жінок з аліментарним типом ожиріння, середній вік пацієнток становив (30 \pm 8 років). Їх було поділено на дві групи: контрольну (КГ, $n=20$ ) і основну (ОГ, $n=22$ ). Жінки ОГ проходили курс відновного лікування за наведеною технологією. Пацієнтки КГ займалися фрізичними вправами за стандартною програмою. Дослідження проводили на базі танцювального клубу «Супаданс», м. Київ. За результатами оцінки стану здоров'я і загального фуннціонального стану всі пацієнтки проходили 12-тижневий курс відновного лікування.

Результати дослідження та їх обговорення. Успішне проведення відновного лікування жінок $з$ ожирінням неможливе без чіткої організації даного процесу, який складається 3 розробки плану реабілітаційного лікування, що включає кілька етапів і залежить від наявності необхідних умов. Як відомо, в сучасній фрізичній реабілітації для профілактики і лікування порушення енергетичного обміну та ожиріння повинні використовуватися фрізичні навантаження різної інтенсивності, які дають можливість зменшувати підшкірні жирові відкладення в різних ділянках тіла, покращувати функціональний стан кардіореспіраторної системи і відновлювати процеси обміну речовин. Найбільш популярним типом фрізичних навантажень, які використовують у фрізичній реабілітації, $є$ лікувальна гімнастика і пішохідні прогулянки.

3 огляду на вищезазначене, нами було запропоновано власну технологію реабілітації для жінок першого зрілого віку з порушенням енергетичного обміну та ожирінням.

По-перше, перед визначенням рівня та підбором оптимальних фрізичних навантажень нами було проведено ретельний теоретичний аналіз впливу вправ різної інтенсивності на метаболічні процеси в організмі жінки. Так, для зниження маси тіла і нормалізації всіх систем організму застосовують аеробні фрізичні навантаження різної інтенсивності і тривалості, при яких (в 
умовах постачання кисню м'язам) забезпечення м'язової діяльності енергією відбувається за рахунок реакцій аеробного розщеплення спочатку вуглеводів, а потім при більш тривалих навантаженнях - жирних кислот, гліцеролкомпонентів, амінокислот, що надходять у м'язову клітину через капілярну мережу і беруть участь в окисному метаболізмі. В умовах недостатнього забезпечення киснем працюючої мускулатури (при навантаженнях максимальної інтенсивності) знижується можливість утилізації ліпідів і внаслідок цього зменшується їх доставка 3 жирових депо. При інтенсивних навантаженнях енерговитрати на дві третини забезпечуються за рахунок вуглеводів і на одну третину - за рахунок ліпідів (здебільшого за рахунок жирних кислот) [3].

Під час навантажень середньої інтенсивності за умови достатнього надходження кисню до тканин частка ліпідів в енергозабезпеченні зростає, а вуглеводів - знижується. Багато зарубіжних авторів [6, 9] підтверджують, що саме при роботі малої і середньої потужності в умовах стійкої рівноваги, коли задовольняється кисневий запит, зростає частка утилізації жирів. Якщо порівнювати запаси енергії в 100 г жиру і 100 г вуглеводів, то відомо, що при розщепленні жиру синтезується в 2 рази більше молекул АТФ, ніж у процесі катаболізму вуглеводів. Запасів вуглеводів в організмі недостатньо, щоб підтримувати фрізичну працездатність тривалий час, тому використовуються запаси жирів. Однак якщо порівняти продукцію АТФ на одиницю поглинання кисню, то виявляється зворотна картина і вуглеводи мають суттєву перевагу. При такому порівнянні вуглеводи на $12 \%$ ефрективніші в поглинанні кисню на 1 молекулу синтезованої АТФ. Разом $з$ тим, шлях забезпечення енергією за рахунок вуглеводних запасів організму, особливо глікогену м'язів, $€$ важливим під час виконання інтенсивних фрізичних навантажень, на нетривалих тренуваннях середньої або малої потужності [9].

По-друге, на тлі теоретичного аналізу механізмів енергозабезпечення виконання вправ різної інтенсивності нами впроваджено в технологію реабілітації методику танцтерапії для жінок першого зрілого віку з ожирінням, акцентуючи увагу на вправах аеробного характеру. Тому, вибираючи фрізичні навантаження для жінок першого зрілого віку з порушенням енергетичного обміну або ожирінням І ступеня, ми зупинилися на циклічних (фізичні вправи, що складаються 3 одних і тих самих елементів - циклів, що багато разів повторюються під час м'язової діяльності), аеробних (з переважанням аеробного компонента енергозабезпечення) фрізичних вправах середньої потужності тривалістю виконання по
1 год 3 рази на тиждень, які покладено в основу фрізичних тренувань у танцтерапії. Ця система тренувань дозволяє забезпечити індивідуальне дозування фрізичних навантажень для тих, хто займається, на основі визначення індивідуального функціонального стану організму і фрізичних можливостей пацієнта.

По-третє, у процесі занять було враховано фрази оваріально-менструального циклу, оскільки в менструальну, овуляторну і передменструальну фрази погіршується фрункціональний стан і знижується працездатність, а в післяменструальну і післяовуляторну - працездатність підвищується.

Виділялися спеціальні мікроцикли, що охоплюють 1-2 дні до менструації і менструальний період, коли знижувався загальний обсяг навантажень і використовувалися навантаження переважно на м'язи рук. Під час виконання фрізичних навантажень проводили контроль пульсового режиму, 1 раз на тиждень здійснювали вимірювання антропометричних показників тіла з подальшою обробкою за допомогою комп'ютерної програми. Рівень інтенсивності і тривалість фрізичних аеробних навантажень підбирали відповідно до індивідуальних можливостей кожної пацієнтки (степ-тест).

По-четверте, при побудові технології комплексної реабілітації для жінок першого зрілого віку 3 порушенням енергетичного обміну та аліментарним ожирінням I ступеня в ОГ застосовували мінеральні води. За даними теоретичного аналізу наукових публікацій з обраної тематики [2], найкращі результати дають сульфатно-натрієві та сульфатно-магнієві мінеральні води, які мають проносну дію, сприяють зниженню всмоктування білків і жирів, додатково посилюють м'язову роботу травного тракту і цим дещо активізують енергетичний обмін. Під впливом вживання мінеральних вод спостерігали позитивні зрушення в ліпідному обміні. Таким чином, вживання мінеральної води супроводжується у жінок з екзогенним ожирінням цілим комплексом реакцій, що виникають не тільки в системі травлення, а й у багатьох органах і тканинах, що сприятливо впливає на гомеостаз. Курс застосування мінеральних вод у нашій програмі становив: 180200 мл за один прийом, 2-3 рази на день протягом усього курсу фрізичної реабілітації.

Як показали клінічні спостереження, у жінок обох груп відзначалося поліпшення загального самопочуття, підвищення настрою, зменшення або цілковита відсутність скарг, які вони висували у початковий період (на головний біль, запаморочення, серцебиття).

Виходячи 3 отриманих даних (рис. 1), очевидно, що для обох груп наприкінці 12-го тижня 


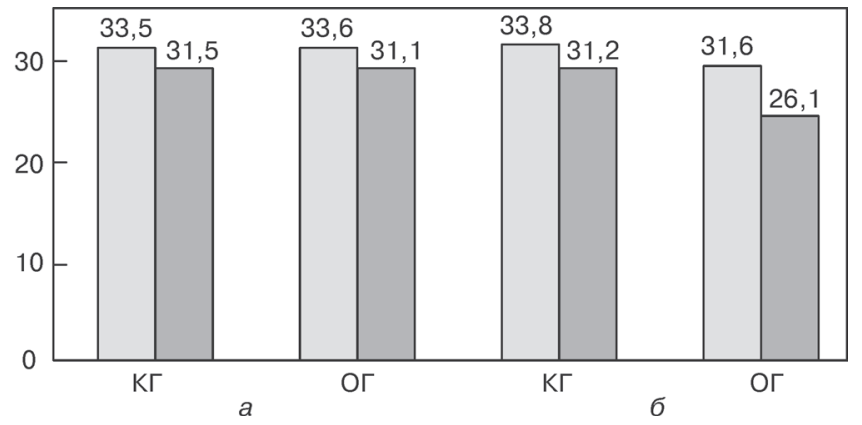

Рисунок 1 - Динаміка показників компонентного складу тіла у пацієнток ОГ та КГ до (а) та після (б) програми лікування: $\square$ - індекс маси тіла (ВМі), кГ $\cdot \mathrm{M}^{-2} ; \square-$ частка жирової тканини (FAT), \% $(p<0,05)$

було характерно зниження загальної маси тіла і зменшення частки жирової тканини.

Разом із тим привертає увагу той фракт, що рівень зниження частки жирової компоненти після розробленої програми був вірогідно більшим в ОГ. Якщо до цієї програми зазначені показники в обох групах вірогідно не відрізнялися (31,5 та 31,1 \% жирової тканини відповідно), то через 12 тиж. їх відмінності були вірогідними (31,2 і 26,1 \% відповідно).

\section{Література}

1. Балюк М. О. Клиническая характеристика больных нейроэндокринной формой гипоталамического синдрома в сочетании с гиперпролактинемией / М. О. Балюк // Медицина сегодня и завтра. - 2003. № 1. - C. 14-17.

2. Гинзбура Ю. Ожирение. Влияние на развитие метаболического синдрома. Профилактика и лечение / Ю. Гинзбург. - М. : Медпрактика, 2002. $-127 \mathrm{c}$.

3. Гринштат А. М. Национальная система физической реабилитации и оздоровления / А. М. Гринштат // Трибуна. - 2008. - № 3-4. C. 43-45.

4. Карпов Ю. А. О гиполипидемической терапии при метаболическом синдроме / Ю. А. Карпов, Е. В. Сорокин // Сердце. - 2006. - 5(7) (31). - С. 356-359.

5. Современные возможности в терапии ожирения / Н. О. Кравчун, И. И. Пилипенко, М. О. Балюк, О. В. Казаков // Проблеми ендокринної патології. - 2004. - № 4. - С. 13-18.

6. Энок Р. М. Основы кинезиологии / Р. М. Энок. - К. : Олимп. лит., 2001. - C. 40-60.

7. American Diabetes Association. Type 2 diabetes in children and adolescents // Pediatrics. - 2000. - Vol. 136. - P. 671-680.

8. Goran M. I. Obesity and risk of type 2 diabetes and cardiovascular disease in children and adolescents / M. I. Goran, G. D. Ball, M. L. Cruz // J. Clin. Endocrinol. Metabol. - 2003. - 88. - P. 1417-1427.

9. Friedland 0 . Obesity and lipid profile in children and adolescencents // Pediatr. Endocrinol. Metab. - 2002 Jul-Aug. - Vol. 15(7). - P. 1011-1016.

10. Keller U. A new class of lipid-lowering drugs: Ezetimibe / U. Keller // Heart Drug. - 2003. - N 3. - P. 214-218.
Розроблена методика диференційованого підбору навантажень для жінок з ожирінням показала досить високу ефективність. Додаткові танцювальні заняття та вправи аеробної спрямованості дозволяють знизити об'єм адипоцитів підшкірної жирової тканини, що сприяє зниженню загальної маси тіла та зменшенню частки жирової тканини.

Отже, на підставі проведених клініко-інструментальних методів досліджень у жінок першого зрілого віку з порушенням енергетичного обміну та ожирінням I ступеня, які займалися аеробними фрізичними тренуваннями, на заняттях танцтерапії отримано більш позитивні результати, що підтверджує її пріоритет під час вибору тактики лікування екзогенно-конституціонального ожиріння у жінок першого зрілого віку.

Висновки. Розроблена методика диференційованого підбору навантажень для жінок 3 ожирінням показала досить високу ефективність. Додаткові танцювальні заняття та вправи аеробної спрямованості дозволяють знизити об’єм адипоцитів підшкірної жирової тканини, що сприяє зниженню загальної маси тіла та зменшенню частки жирової тканини.

\section{References}

1. Balyuk, M.O. (2003). Klinicheskaya harakteristika bolnyih neyroendokrinnoy formoy gipotalamicheskogo sindroma v sochetaniis giperprolaktinemiey [Clinical characteristics of patients with neuroendocrine form of the hypothalamic syndrome in combination with hyperprolactinemia]. Meditsina segodnya i zavtraMedicine today and tomorrow, 1, 14-17 [in Russian].

2. Ginzburg, Y. (2002). Ozhirenie. Vliyanie na razvitie metabolicheskogo sindroma. Profilaktika i lechenie [Obesity. Influence on the development of metabolic syndrome. Prevention and treatment]. Moskva: Medpraktika [in Russian].

3. Grinshtat, A.M. (2008). Natsionalnaya sistema fizicheskoy reabilitatsii i ozdorovleniya [National system of physical rehabilitation and recovery]. Tribuna -Tribune, 3-4, 43-45 [in Russian].

4. Karpov, Y.A., Sorokin, E.V. (2006). O gipolipidemicheskoy terapii pri metabolicheskom syndrome [About hypolipidemic therapy in metabolic syndrome]. Serdtse - Heart, 5(7) (31), 356-359 [in Russian].

5. Kravchun, N.O., Pilipenko, I.I., Balyuk, M.O., Kazakov, O.V. (2004). Sovremennyie vozmozhnosti $v$ terapii ozhireniya [Modern opportunities in the therapy of obesity]. Problemi endokrinnoyi patologiyi - Problems of endocrine pathology, 4, 13-18 [in Russian].

6. Enok, R.M. (2001). Osnovyi kineziologii [Fundamentals of kinesiology]. Kiev: Olimpiyskaya literatura, 40-60 [in Russian].

7. American Diabetes Association (2000). Type 2 diabetes in children and adolescents. Pediatrics, Vol. 136, 671-680.

8. Goran, M.I., Ball, G.D., Cruz, M.L. (2003). Obesity and risk of type 2 diabetes and cardiovascular disease in children and adolescents. J. Clin. Endocrinol. Metabol., 88, 1417-1427.

9. Friedland, O. (2002 Jul-Aug). Obesity and lipid profile in children and adolescencents. Pediatr. Endocrinol. Metab., Vol. 15(7), 1011-1016.

10. Keller, U. (2003). A new class of lipid-lowering drugs: Ezetimibe. Heart Drug, 3, 214-218. 